\title{
Front Matter: Volume 11553
}

, "Front Matter: Volume 11553," Proc. SPIE 11553, Optics in Health Care and Biomedical Optics X, 1155301 (9 November 2020); doi: 10.1117/12.2585933

SPIE. Event: SPIE/COS Photonics Asia, 2020, Online Only 


\title{
PROCEEDINGS OF SPIE
}

\section{Optics in Health Care and Biomedical Optics $X$}

\author{
Qingming Luo \\ Xingde Li \\ Ying Gu \\ Dan Zhu \\ Editors
}

\section{1-16 October 2020 \\ Online Only, China}

\author{
Sponsored by \\ SPIE \\ COS-Chinese Optical Society
}

Cooperating Organizations

Tsinghua University (China) • Peking University (China) • University of Science and Technology of China (China) • Zhejiang University (China) • Tianjin University (China) Beijing Institute of Technology (China) • Beijing University of Posts and Telecommunications (China) • Nankai University (China) • Changchun University of Science and Technology (China) • University of Shanghai for Science and Technology (China) • Capital Normal University (China) • Huazhong University of Science and Technology (China) • Beijing Jiaotong University (China) • China Jiliang University (China) - Shanghai Institute of Optics and Fine Mechanics, CAS (China) - Changchun Institute of Optics, Fine Mechanics and Physics, CAS (China) • Institute of Semiconductors, CAS (China) • Institute of Optics and Electronics, CAS (China) • Institute of Physics, CAS (China) - Shanghai Institute of Technical Physics, CAS (China) • China Instrument and Control Society (China) • Japan Optical Society (Japan) • Korea Optical Society (Korea, Republic of) • Australia Optical Society (Australia) • Singapore Optical Society (Singapore) • European Optical Society

Supporting Organizations

China Association for Science and Technology (CAST) (China)

Department of Information of National Nature Science Foundation, China (NSFC) (China)

Published by

SPIE

\section{Volume 11553}


The papers in this volume were part of the technical conference cited on the cover and title page. Papers were selected and subject to review by the editors and conference program committee. Some conference presentations may not be available for publication. Additional papers and presentation recordings may be available online in the SPIE Digital Library at SPIEDigitalLibrary.org.

The papers reflect the work and thoughts of the authors and are published herein as submitted. The publisher is not responsible for the validity of the information or for any outcomes resulting from reliance thereon.

Please use the following format to cite material from these proceedings:

Author(s), "Title of Paper," in Optics in Health Care and Biomedical Optics $X$, edited by Qingming Luo, Xingde Li, Ying Gu, Dan Zhu, Proceedings of SPIE Vol. 11553 (SPIE, Bellingham, WA, 2020) Sevendigit Article CID Number.

ISSN: 0277-786X

ISSN: 1996-756X (electronic)

ISBN: 9781510639218

ISBN: 9781510639225 (electronic)

Published by

SPIE

P.O. Box 10, Bellingham, Washington 98227-0010 USA

Telephone +1 3606763290 (Pacific Time) · Fax +1 3606471445

SPIE.org

Copyright (c) 2020, Society of Photo-Optical Instrumentation Engineers.

Copying of material in this book for internal or personal use, or for the internal or personal use of specific clients, beyond the fair use provisions granted by the U.S. Copyright Law is authorized by SPIE subject to payment of copying fees. The Transactional Reporting Service base fee for this volume is $\$ 21.00$ per article (or portion thereof), which should be paid directly to the Copyright Clearance Center (CCC), 222 Rosewood Drive, Danvers, MA 01923. Payment may also be made electronically through CCC Online at copyright.com. Other copying for republication, resale, advertising or promotion, or any form of systematic or multiple reproduction of any material in this book is prohibited except with permission in writing from the publisher. The CCC fee code is $0277-$ $786 \mathrm{X} / 20 / \$ 21.00$.

Printed in the United States of America by Curran Associates, Inc., under license from SPIE.

Publication of record for individual papers is online in the SPIE Digital Library.

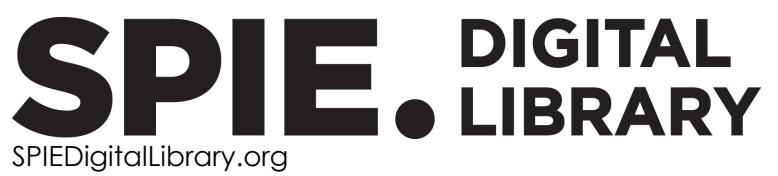

Paper Numbering: Proceedings of SPIE follow an e-First publication model. A unique citation identifier (CID) number is assigned to each article at the time of publication. Utilization of CIDs allows articles to be fully citable as soon as they are published online, and connects the same identifier to all online and print versions of the publication. SPIE uses a seven-digit CID article numbering system structured as follows:

- The first five digits correspond to the SPIE volume number.

- The last two digits indicate publication order within the volume using a Base 36 numbering system employing both numerals and letters. These two-number sets start with $00,01,02,03,04$, 05, 06, 07, 08, 09, OA, OB ... 0Z, followed by 10-1Z, 20-2Z, etc. The CID Number appears on each page of the manuscript. 


\section{Contents}

NOVEL MICROSCOPY

1155304 A micron precision fiber bundle coupler for confocal endomicroscope [11553-3]

1155306 Super-resolution acoustic-resolution photoacoustic microscopy by a novel algorithm [11553-5]

1155307 Real-time calcium imaging by the interaction of adenosine receptors in living HEK293T cells [11553-6]

$115530 \mathrm{~A}$ Assessing structural features of tuberculosis using Mueller matrix derived parameters: a quantitative method to distinguish between Crohn's disease and gastrointestinal luminal tuberculosis [11553-9]

\section{OCT AND APPLICATIONS}

$11553 \mathrm{OF} \quad$ Study of imaging performance of mouse eyes based on optical coherence tomography and ray tracing techniques [11553-14]

11553 OG In vivo characterization of human disease models based on adult zebrafish with optical coherence tomography [11553-15]

\section{TRANSLATIONAL OPTICAL TECHNIQUES FOR CLINICAL MEDICINE}

11553 OT Heptamethine cyanine-based small molecular cancer theranostic agents [11553-28]

11553 OV Quantitative detection of protoporphyrin IX (PpIX) fluorescence in tissues [11553-30]

11553 OX Dual-tracer PET image direct reconstruction and separation based on three-dimensional encoder-decoder network [11553-34]

\section{NANOBIOPHOTONICS}

1155316 Atto-level nanobiophotonic sensing approach using silicon technology [11553-44] 
$115531 \mathrm{~A}$ Spatially resolved diffuse reflectance and autofluorescence photon depth distribution in human skin spectroscopy: a modeling study [1 1553-49]

11553 1C Parallel acquisition of 2D multifocal Raman spectroscopy using compressive sensing [11553-51]

11553 ID Rapid Stokes polarimetry for studying the process of optical tissue clearing [11553-52]

11553 IG Machine learning applications for spectral analysis of human exhaled breath for early diagnosis of diseases [11553-110]

\section{POSTER SESSION}

$115531 \mathrm{H} \quad$ Rapid identification of two types of tissue necrosis in breast tumor using multiphoton microscopy [11553-48]

$1155311 \quad$ Computed extended depth of field optical-resolution photoacoustic microscope using wavelet transform fusion [11553-55]

$115531 \mathrm{~J}$ Simulation investigation of photoacoustic signal generation in the prostate tissue [11553-56]

$11553 \mathrm{IL} \quad$ Simulation of the measurement error of independent emission-spectral unmixing FRET [11553-58]

$115531 \mathrm{M} \quad$ Light absorption distribution for photoacoustic imaging of bladder by use of endoscopic light illumination [11553-59]

$1155310 \quad$ Methods on optimizing OPSI [11553-61]

11553 1P Merits of vision in presence of light scattering using Tiffen ProMist filters [1 1553-62]

$115531 Q \quad$ Surface-enhanced Raman scattering of secretory proteins from LO2 and HepG2 [1 1553-63]

11553 IR Defection of cancerous esophageal tissue by Raman spectroscopy and multivariate analysis of extracellular fluid [1 1553-64]

11553 is A Deep ADMM-net for iterative low-count PET reconstruction [11553-65]

11553 1T A serum albumin analysis technique combining hydroxyapatite (HAp) and surface-enhanced Raman scattering for noninvasive breast cancer screening [11553-66]

$115531 \mathrm{U}$ Development and performance evaluation of portable $405 \mathrm{~nm}$ laser-induced fluorescence detector [11553-67]

$115531 \mathrm{~V}$ Dual-channel wide-field microscopic detection for mast cells degranulation using nanomaterial-based FRET biosensor [1 1553-68] 
11553 IW Effects of multiple factors on photoacoustic detection of glucose based on back propagation neural network combined with intelligent optimization algorithms [1 1553-69]

11553 IY Classification of skin cancer based on fluorescence lifetime imaging and machine learning [11553-71]

1155320 Label-free multiphoton imaging to identify two types of tumor-infiltrating lymphocytes in breast tumor microenvironment [11553-73]

$1155321 \quad$ Monitoring collagen changes in tumor microenvironment using multiphoton microscopy [11553-74]

1155322 Photothermal therapy method based on photoacoustic/ultrasonic dual-mode temperature measurement and regulation [11553-75]

1155323 Identification of blood vessel invasion in breast tumor microenvironment by multiphoton microscopy [11553-76]

1155328 Optimization method of diffuse optical tomography reconstruction based on neural network [11553-81]

1155329 Spectrum analysis of acousto-optic signal modulated by ultrasound at different frequency in scattering medium [11553-82]

$115532 \mathrm{~B} \quad$ Assessing pharmacokinetics of indocyanine green in liver injury mice using dynamic diffuse fluorescence tomography system [11553-84]

$115532 \mathrm{C}$ Differentiation of submicron particles with two-dimensional light scattering technology [11553-85]

$115532 D \quad$ SERS signal of serum proteins purified with cellulose acetate membrane [11553-86]

$115532 \mathrm{E} \quad$ Photothermal response of skin by OCT and infrared thermal imager [11553-87]

$115532 \mathrm{~J} \quad$ High-content 2D light scattering flow cytometry for label-free classification of cervical carcinoma cells with deep learning [11553-92]

$115532 \mathrm{~K} \quad$ Negativity artifacts analysis in back-projection based photoacoustic tomography [1 1553-93]

$115532 \mathrm{~L}$ Simultaneous algebraic reconstruction technique based on total variation for photoacoustic image [11553-94]

$115532 \mathrm{M}$ Highly sensitive detection of DNA fragments by fluorescence correlation spectroscopy [11553-95]

11553 2N Quantitatively distinguishing typical pathological features between different breast tissues using polarimetry feature parameters [11553-96]

1155320 High-speed wide-field optical-sectioning fluorescence microscopy based on one-shot structured illumination [1 1553-97] 
$115532 \mathrm{P} \quad$ Analysis of image features for the characterization of skin optical clearing kinetics performed on in vivo and ex vivo human skin using Linefield-Confocal Optical Coherence Tomography (LC-OCT) [11553-98]

$115532 \mathrm{R} \quad$ Variation of optical attenuation coefficient during ischemia-reperfusion process of rabbit kidney measured by optical coherence tomography [11553-100]

$115532 \mathrm{~T} \quad$ Evaluation of different denoising algorithms for OCT image denoising [1 1553-102]

$115532 \mathrm{U} \quad$ Skin melanoma detection based on hyperspectral imaging and deep-learning techniques [11553-103]

$115532 \mathrm{~W}$ Application of convolutional neural network in signal classification for in vivo photoacoustic flow cytometry [11553-105]

$115532 \mathrm{X} \quad$ Volume scanning-based light scattering microscopy for fast 3D localization of single particles [11553-106]

$1155322 \quad$ Estimation of the advanced glycation end products accumulated by sclera using autofluorescence [11553-108]

1155330 Diminution of melanin influence on the level of skin autofluorescence utilized for the estimation of advanced glycation end products level using green LED [1 1553-109] 